\title{
EVALUASI TEKNIK OPERASIONAL PERSAMPAHAN KECAMATAN SAMBAS
}

Agung Ananda Saugi, Dian Rahayu Jati, Yulisa Fitrianingsih

Program Studi Teknik Lingkungan Fakultas Teknik Universitas Tanjungpura, Pontianak Email: agungsaugi@gmail.com

\begin{abstract}
ABSTRAK
Permasalahan sampah timbul karena tidak seimbangnya produksi sampah dengan pengelolaannya. Menurut data dari Dinas Kependudukan dan Pencatatan Sipil, Kecamatan Sambas memiliki 56.787 warga pada tahun 2015. Setiap hari warga Kecamatan Sambas menghasilkan sampah sekitar $156,164 \mathrm{~m}^{3} /$ hari dan hanya $45 \%$ warga yang terlayani dengan asumsi satu orang menghasilkan 2,75 liter sampah perhari. Kinerja dari sistem pengelolaan sampah pada suatu kawasan atau wilayah akan menentukan kondisi lingkungan pada wilayah tersebut. Pengelolaan sampah di Kecamatan Sambas merupakan suatu permasalahan yang menjadi prioritas untuk diselesaikan. Peningkatan volume sampah yang dihasilkan dari berbagai aktivitas masyarakat membutuhkan penanganan dengan teknik operasional pengelolaan sampah perkotaan agar sampah - sampah yang dihasilkan oleh aktivitas masyarakat tidak menimbulkan berbagai masalah yang dapat mengganggu lingkungan masyarakat. Penelitian ini bertujuan untuk mengetahui umur zona timbunan TPA Sorat dan mengevaluasi teknik operasional persampahan di Kecamatan Sambas. Metode yang digunakan adalah pengamatan langsung di lapangan dan membandingkan antara kondisi teknik operasional di Kecamatan Sambas dengan SNI 19-24542002 tentang Tata Cara Teknik Operasional Pengelolaan Sampah Perkotaan. Analisis data dilakukan dengan melakukan perhitungan sesuai dengan SNI 3242-2008 tentang Pengelolaan Sampah di Permukiman. Hasil penelitian menunjukkan bahwa umur zona timbunan TPA Sorat diprediksi dapat mencapai hingga 9 tahun kedepan dengan akumulasi timbunan sampah mencapai $122.315 \mathrm{~m}^{3}$ dan zona timbunan yang dipersiapkan seluas $1,25 \mathrm{Ha}$, yaitu dari tahun 2016 sampai tahun 2025 serta teknik operasional persampahan pada aspek pengumpulan sampah dan pengangkutan sampah di Kecamatan Sambas masih belum seluruhnya menerapkan SNI 19-2454-2002.
\end{abstract}

Kata Kunci : Kecamatan Sambas, TPA Sorat, Teknik Operasional

\begin{abstract}
Waste problem arises because the imbalance of production waste management. According to data from the Department of Population and Civil Registration, Sambas district had 56.787 citizens in 2015. Each day Sambas District residents produce rubbish around 156,164 $\mathrm{m}^{3} /$ day and only $45 \%$ of citizens who served with the assumption that one person produces 2,75 liters of garbage per day. The performance of the solid waste management system in a region or territory will determine the environmental conditions in the region. Waste management in the Sambas District is a priority issues to be resolved. Increasing the volume of waste generated from a variety of community activities need to be addressed with the operational technique of urban waste management in order to garbage generated by the activity of the community does not pose a variety of problems that can disrupt society. This study aims to determine the age of the landfill heap zone Sorat and evaluate the operational technique of solid waste in the district of Sambas. The method used was direct observation in the field and comparing the technical and operational conditions in the district of Sambas with SNI 19-2454-2002 on Procedures for Management of Urban Waste Operations Engineering. Data analysis was performed by calculating in accordance with SNI 3242-2008 Waste Management in the Settlement. The results showed that the age of the landfill heap zone Sorat predicted to reach up to 9 years ahead with accumulated waste piles reached $122.315 \mathrm{~m}^{3}$ and prepared heap zone of 1,25 ha, from 2016 to 2025 as well as the technical aspects of waste operational on garbage collection and transportation of garbage in the Sambas District yet fully applied SNI 19-2454-2002.
\end{abstract}

Keywords: Sambas District, Sorat Landfill, Operational Technique 


\section{PENDAHULUAN}

Kecamatan Sambas memiliki memiliki tingkat kepadatan penduduk sekitar 198 jiwa per $/ \mathrm{Km}^{2}$. Pada Tahun 2011 jumlah penduduk Kecamatan Sambas berjumlah 49.046 jiwa hingga pada tahun 2015 berjumlah 56.787 jiwa. Kecamatan Sambas memiliki luas wilayah sebesar 246,66 $\mathrm{Km}^{2}$ dan luas daerah Kecamatan Sambas adalah 3,86 \% dari luas Kabupaten Sambas (Disdukcapil Kab. Sambas, 2014). Permasalahan sampah timbul karena tidak seimbangnya produksi sampah dengan pengelolaannya. Menurut data dari Dinas Pekerjaan Umum Kabupaten Sambas pada tahun 2015 Setiap hari warga Kecamatan Sambas menghasilkan sampah sekitar $156,164 \mathrm{~m}^{3} /$ hari dan hanya $45 \%$ warga yang terlayani dengan asumsi satu orang menghasilkan 2,75 liter sampah perhari.

TPA Sorat adalah TPA yang posisinya berada di Kecamatan Sambas, sehingga pemrosesan akhir sampah di Kecamatan Sambas dilaksanakan di TPA Sorat. Lahan yang sudah dibebaskan seluas $4 \mathrm{Ha}$ dan dengan luas area zona timbunan yang dipersiapkan sekitar 1,25 Ha. Adapun metode pengelolaan yang dilakukan di tempat pemrosesan akhir Sorat sudah menerapkan Controlled Landfill, namun prasarana berupa kendaraan untuk pengangkutan sampah dari tempat pembuangan sementara ke tempat pemrosesan akhir tentu masih sangat kurang dan kondisi TPS masih menggunakan TPS konvensional. Teknik operasional pengelolaaan sampah di Kecamatan Sambas masih perlu dilakukan evaluasi sehingga dapat memenuhi kriteria yang sesuai dengan SNI 192454-2002 yang merupakan standar tata cara teknik operasional pengelolaan sampah perkotaan. Penelitian ini dilakukan untuk menganalisis umur zona timbunan di TPA Sorat dan mengevaluasi teknik operasional persampahan di Kecamatan Sambas.

\section{METODE PENELITIAN}

\section{A. LOKASI DAN WAKTU PENELITIAN}

Lokasi penelitian dilakukan di Kecamatan Sambas. Kecamatan Sambas merupakan ibu kota dari Kabupaten Sambas. Luas Kecamatan Sambas $246,66 \mathrm{~km}^{2}$, luas Kecamatan Sambas adalah 3,86 \% dari luas total Kabupaten Sambas.

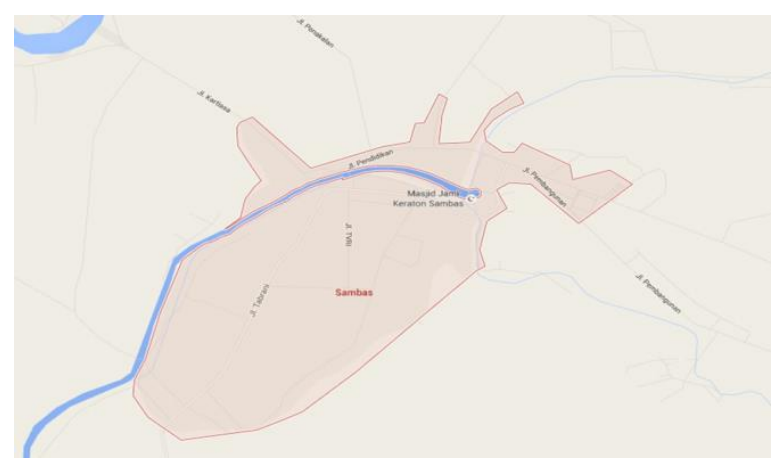

Gambar 1. Peta Lokasi Penelitian

Waktu yang dibutuhkan untuk melakukan penelitian ini adalah selama 6 bulan yaitu terhitung mulai dari Bulan Mei 2016 hingga Bulan September 2016.

\section{B. METODE PENELITIAN}

\section{- Teknik Pengumpulan Data}

Untuk mendapatkan informasi yang memadai dan representatif mengenai teknis operasional pengelolaan sampah pada Kecamatan Sambas, evaluasi ini akan menggunakan teknik pengumpulan data sebagai berikut : 
1. Pengumpulan data di lapangan yang disebut dengan data primer, dengan cara wawancara kepada key person yaitu Kepala Bidang Kebersihan, Pertamanan, dan Perkuburan Dinas Pekerjaan Umum Kabupaten Sambas. Observasi dilapangan atau pengamatan langsung di lapangan untuk mengetahui jumlah timbulan sampah dan kondisi eksisiting TPS dan alat pengangkut sampah.

2. Pengumpulan data dengan meminta data dari sumbernya yang disebut dengan data sekunder, yaitu pengumpulan data dari instansi - instansi yang terkait dengan evaluasi teknik operasional pengelolaan sampah seperti Dinas Pekerjaan Umum, BAPPEDA, BPS, dan lain sebagainya.

\section{- Proyeksi Jumlah Penduduk}

Perhitungan terhadap proyeksi jumlah penduduk sangat penting dilakukan untuk mengetahui jumlah timbulan sampah yang dihasilkan selama periode perencanaan. Metode yang dapat digunakan dalam perhitungan proyeksi jumlah penduduk adalah sebagai berikut (Adioetomo dan Samosir, 2010):

a. Metode Aritmatik

$$
\mathrm{Pn}=\mathrm{Po}+\mathrm{Ka}(\mathrm{Tn}-\mathrm{To}) ; \mathrm{Ka}=\frac{\mathrm{P} 2-\mathrm{P} 1}{T 2-T 1}
$$

Pilihan rumus proyeksi jumlah penduduk yang akan digunakan ditentukan dengan hasil perhitungan yang paling mendekati kebenaran harus dilakukan analisis dengan menghitung standar deviasi atau koefisien korelasi. Rumus standar deviasi dan koefisien korelasi adalah sebagai berikut:

(1) Standar Deviasi :

$S=\frac{\Sigma(\mathrm{x}-\mathrm{Xi})^{2}}{n-1}$ untuk $n>1, S=\frac{\Sigma(\mathrm{x}-\mathrm{xi})^{2}}{n}$ untuk $n=1$

(2) Koefisien Korelasi

Metode perhitungan proyeksi jumlah penduduk yang menghasilkan koefisien paling mendekati 1 adalah metode yang terpilih.

$$
r=\frac{\text { Faktor korelasi untuk metode Geometri }}{n \sum x y-\sum x \cdot \sum y}
$$

\section{- Perhitungan Timbulan Sampah}

Perhitungan jumlah timbulan sampah dapat dihitung dengan persamaan pada SNI 19-3983-1995 sebagai berikut :

Total Timbulan Sampah = Jumlah Penduduk $\mathrm{x}$ volume sampah

\section{- Analisis Kebutuhan Pewadahan}

Kapasitas dan jumlah wadah disesuaikan dengan kebutuhan yang telah dihitung dari setiap sumber sampah, dimana pengumpulan sampah dilakukan 1 kali sehari. Setiap sumber sampah menggunakan 2 jenis wadah yaitu sampah organik dan sampah anorganik dengan kapasitas yang sama. Penggunaan kapasitas wadah yang sama untuk sampah organik dan anorganik dikarenakan nilai estetika yang lebih baik, sehingga tidak terjadi perbedaan ukuran wadah yang bersebelahan (SNI 19-2454-2002).

\section{- Analisis Kebutuhan Kontainer}

Perhitungan jumlah TPS dapat dihitung dengan persamaan pada SNI-3242-2008 sebagai berikut :

$$
\mathrm{CP}=\frac{\text { Jumlah TS }}{\text { Kc } \times \text { Fpx Ritasi }}
$$




\section{- Analisis Kebutuhan Alat Angkut}

Jumlah armroll truck yang digunakan dapat dihitung menggunakan persamaan yang ada pada SNI-3242-2008 sebagai berikut:

Kebutuhan alat anagkut $=\frac{\mathrm{CP}}{\text { Ritasi }}$

\section{- Analisis Umur Zona Timbunan TPA}

Analisis umur lahan zona timbunan TPA dilakukan untuk mengetahui lamanya lahan zona timbunan dapat menampung residu sampah yang masuk ke TPA. Umur lahan zona timbunan dapat diketahui dengan cara membandingkan lahan zona timbunan yang sudah dipersiapkan dengan kebutuhan lahan zona timbunan yang dibutuhkan. Berikut perhitungan untuk mencari zona timbunan yang dibutuhkan sebagai berikut :

$$
\text { Kebutuhan zona timbunan }=\frac{\text { Akumulasi timbunan }}{\text { Tinggi timbunam }}
$$

\section{- Evaluasi Teknik Operasional Pengelolaan Sampah Di Kecamatan Sambas}

Analisis ini untuk mengetahui kinerja sistem pengelolaan sampah di Kecamatan Sambas. Jadi pada teknik ini mengaitkan pengelolaan yang diterapkan pada Kecamatan Sambas dengan aspek teknik operasional yang diatur dalam SNI 19-2454-2002 tentang tata cara teknik operasional pengelolaan sampah perkotaan. Teknik analisis yang digunakan setelah data keseluruhan terkumpul yaitu dengan membandingkan antara kondisi operasional di lapangan dengan ketentuan di SNI 19-2454-2002 dalam bentuk tabel.

\section{HASIL DAN PEMBAHASAN}

\section{A. Proyeksi Jumlah Penduduk}

Proyeksi jumlah penduduk Kecamatan Sambas dilakukan sampai 10 tahun kedepan atau sampai tahun 2025. Untuk mengetahui metode proyeksi yang digunakan, dilakukan dengan menghitung nilai koefisien korelasi. Metode proyeksi yang dipilih dari ketiga metode yang digunakan adalah metode aritmatika karena nilai koefisien korelasinya mencapai satu dibandingkan dengan 2 metode lainnya. Berikut perhitungan untuk mencari nilai konstanta aritmatik :

$$
K A=\frac{56.787-49.046}{2015-2011}=1935
$$

Maka perhitungan proyeksi penduduk di Kecamatan Sambas menggunakan metode artimatika pada tahun 2015 sebagai berikut:

$\mathrm{P}_{2016}=56.787+(1935 \times(2016-2015)$

$\mathrm{P}_{2016}=58.722$ jiwa

Perhitungan sampai tahun 2025 dilakukan dengan cara yang sama dengan perhitungan pada tahun 2016. Berikut adalah tabel yang menunjukkan hasil perhitungan proyeksi jumlah penduduk yang akan digunakan dengan metode geometri untuk 10 tahun yaitu tahun 2016 hingga 2025:

Tabel 1 Hasil Proyeksi Jumlah Penduduk (2016 - 2025)

\begin{tabular}{ccc}
\hline No. & Tahun & Jumlah \\
\hline 1 & 2016 & 58722 \\
2 & 2017 & 60658 \\
3 & 2018 & 62593 \\
4 & 2019 & 64528 \\
5 & 2020 & 66463
\end{tabular}




\begin{tabular}{ccc}
6 & 2021 & 68399 \\
7 & 2022 & 70334 \\
8 & 2023 & 72269 \\
9 & 2024 & 74204 \\
10 & 2025 & 76140 \\
\hline \multicolumn{3}{l}{ Sumber: Hasil Analisis,2016 }
\end{tabular}

Dari Tabel 1 diketahui bahwa proyeksi pertumbuhan penduduk selalu mengalami peningkatan setiap tahunnya.

\section{B Analisis Timbulan Sampah}

Jumlah Penduduk Kecamatan Sambas pada tahun 2016 berdasarkan proyeksi adalah 58.722 jiwa, sedangkan asumsi timbulan sampah per orang dalam 1 hari adalah 2,75 L/org/hari (Dinas Pekerjaan Umum Kab. Sambas, 2015). Estimasi timbulan sampah domestik pertahunnya, dapat dilihat pada Tabel 2

Contoh Perhitungan Timbulan Sampah di Kecamatan Sambas Tahun 2016:

Timbulan sampah per orang/ hari = Jumlah Penduduk $x$ Volume Sampah

$$
\begin{aligned}
& =58.722 \text { jiwa } \times 2,75 \mathrm{I} / \mathrm{o} / \text { hari } \\
& =161.486 \text { liter } / \text { hari }: 1000 \\
& =161,486 \mathrm{~m}^{3} / \text { Hari }
\end{aligned}
$$

Perhitungan sampai tahun 2025 dilakukan dengan cara yang sama dengan perhitungan pada tahun 2016.

Berikut contoh perhitungan untuk mengetahui timbulan sampah yang akan diangkut ke TPA pada tahun 2016 :

Sampah yang diangkut ke TPA $=\frac{\text { Sampahyang harus diangkut } x \text { Tingkat pelayanar }}{\text { Tingkatpemadgtadi }}$

$$
\begin{aligned}
& =\frac{161,49 \mathrm{~m}^{3} / \text { hari } 47 \%}{\left(\frac{0,4 \mathrm{Kg} / \mathrm{m}^{2}}{0,0 \mathrm{Kg} / \mathrm{m}^{2}}\right)} \\
& =37,95 \mathrm{~m}^{3} / \text { hari }
\end{aligned}
$$

Untuk perhitungan hingga 2025 dilakukan dengan cara yang sama dengan perhitungan pada tahun 2016. Hasil dari estimasi total timbulan sampah yang diangkut ke TPA dapat dilihat pada Tabel 2 dimana sampah yang diangkut ke TPA mengalami pemadatan dengan faktor densitas sumber sebesar $0,2 \mathrm{~kg} / \mathrm{m}^{3}$ dan faktor densitas alat angkut sebesar $0,4 \mathrm{~kg} / \mathrm{m}^{3}$ (Enri Damanhuri, 2010).

Tabel 2 Estimasi Total Timbulan Sampah Yang Diangkut Ke TPA

\begin{tabular}{ccccc}
\hline No & Tahun & $\begin{array}{c}\text { Volume sampah } \\
\text { yang harus di } \\
\text { angkut (m } \mathbf{3} \text { /hari) }\end{array}$ & $\begin{array}{c}\text { Tingkat } \\
\text { pelayanan } \\
\text { (\%) }\end{array}$ & $\begin{array}{c}\text { Sampah yang } \\
\text { diangkut ke TPA } \\
\text { ( }^{\mathbf{3}} \text { /hari) }\end{array}$ \\
\hline 1 & 2016 & 161,49 & 47 & 37,95 \\
2 & 2017 & 166,81 & 49 & 40,87 \\
3 & 2018 & 172,13 & 51 & 43,89 \\
4 & 2019 & 177,45 & 53 & 47,02 \\
5 & 2020 & 182,77 & 55 & 50,26 \\
6 & 2021 & 188,10 & 57 & 53,61 \\
7 & 2022 & 193,42 & 59 & 57,06 \\
8 & 2023 & 198,74 & 61 & 60,62 \\
9 & 2024 & 204,06 & 63 & 64,28 \\
10 & 2025 & 209,38 & 65 & 68,05 \\
\hline
\end{tabular}

Sumber : Hasil Analisis, 2016 
Dilihat dari 3 tahun terakhir bahwa rata-rata pelayanan pengangkutan sampah terus mengalami peningkatan $2 \%$, sehingga dapat diproyeksikan setiap tahunnya tingkat pelayanan akan pengangkutan sampah terus meningkat sebesar $2 \%$. Peningkatan pelayanan pengangkutan sampah masih relatif kecil dan masih jauh dari target yang diharapkan dapat mencapai 70\% pada tahun 2015 yang ditetapkan oleh Peraturan Menteri Pekerjaan Umum Nomor: 03/PRT/M/2013 Tentang Penyelenggaraan Prasarana Dan Sarana Persampahan Dalam Penanganan Sampah Rumah Tangga Dan Sampah Sejenis Sampah Rumah Tangga.

\section{Analisis Kebutuhan Pewadahan}

Pada Kecamatan Sambas jumlah timbulan sampah pada setiap satu unit permukiman sebesar 13,75 liter/unit/hari dengan jumlah anggota keluarga sebanyak 5 jiwa perunit rumah dan timbulan sampah 2,75 liter/orang/hari. Menurut dokumen Profil Kebersihan Kabupaten Sambas tahun 2015 bahwa komposisi sampah terdiri atas 80\% sampah organik dan $20 \%$ sampah anorganik. Berikut perhitungan komposisi wadah untuk Kecamatan Sambas:

$$
\begin{aligned}
\text { Wadah Sampah Organik } & =\text { Jumlah timbulan sampah per KK } \times 80 \% \\
& =13,75 \text { liter/unit/hari } \times 80 \% \\
& =11 \text { liter } \\
\text { Wadah Sampah Anorganik } & =\text { Jumlah timbulan sampah per KK } \times 20 \% \\
& =13,75 \text { liter/unit/hari } \times 20 \% \\
& =3 \text { liter }
\end{aligned}
$$

Kapasitas dan jumlah wadah disesuaikan dengan kebutuhan yang telah dihitung dari setiap sumber sampah, dimana pengumpulan sampah dilakukan 1 kali sehari. Setiap sumber sampah menggunakan 2 jenis wadah yaitu sampah organik dan sampah anorganik dengan kapasitas yang sama. Jumlah wadah individu dan kapasitas yang digunakan berdasarkan jumlah anggota keluarga pada satu rumah dan volume sampah yang dihasilkan. Salah satu kapasitas wadah yang digunakan dalam pewadahan individu adalah kapasitas 15 liter.

\section{Analisis Kebutuhan Kontainer}

Berikut contoh perhitungan estimasi jumlah Kontainer untuk keperluan fasilitas di TPS yang dibutuhkan untuk tahun 2016:

$$
\begin{aligned}
C P & =\frac{\text { Jumlah TS }}{\text { Kc x Fpx Ritasi }} \\
& =\frac{37,95 \mathrm{~m}^{3} / \text { hari }}{8 \mathrm{~m}^{3} \times 0,4 \times 3} \\
& =4 \text { Unit }
\end{aligned}
$$

Berdasarkan hasil perhitungan didapatlah jumlah kontainer yang akan digunakan pada tahun 2016 sebanyak 4 unit dengan jumlah ritasi 3/hari yang merujuk pada keputusan Menteri Permukiman Dan Prasarana Wilayah No.534/KPTS/M/2001. Setiap TPS akan memiliki 1 kontainer sehingga jumlah TPS yang ada di Kecamatan Sambas juga berjumlah 4 TPS dan kontainer tersebut memiliki kapasitas $8 \mathrm{~m}^{3}$.

Perhitungan sampai tahun 2025 dilakukan dengan cara yang sama dengan perhitungan pada tahun 2016. TPS tersebut akan diletakkan pada lokasi yang telah memenuhi kriteria sesuai dengan SNI 19-2454-2002.

Analisis Kebutuhan Alat Angkut

Berikut contoh perhitungan kebutuhan alat angkut untuk tahun 2016:

$$
\text { Kebutuhan alat angkut }=\frac{\text { JumlahTPS }}{\text { Ritasi }}
$$




$$
\begin{aligned}
& =\frac{4 \text { unit kontainer }}{3 \text { ritasi }} \\
& =1 \text { unit armroll truck }
\end{aligned}
$$

Berdasarkan hasil perhitungan didapatlah jumlah armroll truck yang akan digunakan pada tahun 2016 sebanyak 1 unit dengan 3 ritasi/hari yang merujuk kepada keputusan Menteri Permukiman Dan Prasarana Wilayah No.534/KPTS/M/2001. Perhitungan sampai tahun 2025 dilakukan dengan cara yang sama dengan perhitungan pada tahun 2016. Armroll truck yang akan digunakan memiliki dimensi kontainer yang sama dengan kontainer sampah di TPS. Armroll truck yang digunakan selalu membawa 1 kontainer kosong yang akan ditukar dengan yang berisi saat proses pengangkutan.

\section{F Analisis Umur Zona Timbunan TPA}

Luas lahan untuk zona timbunan sampah yang dipersiapkan seluas $\pm 1,25$ Ha dan persentase pelayanan sampah diperkirakan akan meningkat sekitar 1-3\%, dengan menerapkan timbunan sampah sebanyak 3 lift. Persentasi sampah yang dirug sebesar $80 \%$, dengan tingkat pemadatan di alat pengangkut dan di TPA sebesar $0,6 \mathrm{Kg} / \mathrm{m}^{3}$ dan $0,4 \mathrm{Kg} / \mathrm{m}^{3}$, dan tanah penutup sebesar $20 \%$ dari volume sampah yang diurug setelah kompaksi (DED TPA Sorat, 2012).

Berikut contoh perhitungan untuk mengetahui zona timbunan yang berada di TPA Sorat :

a. Kebutuhan zona timbunan tahun 2016 :

$$
\begin{aligned}
& \frac{\text { Akumulasi timbunan }}{\text { Tinggi timbunan }}=\frac{8.865 \mathrm{~m}^{3}}{10 \mathrm{~m}}=886 \mathrm{~m}^{2} \\
& \frac{886 \mathrm{~m}^{2}}{10.000}=0,09 \mathrm{Ha}
\end{aligned}
$$

Untuk perhitungan tahun selanjutnya dilakukan dengan cara yang sama pada perhitungan di Tahun 2016. Berikut tabel yang akan menyajikan data mengenai informasi umur zona timbunan pada TPA Sorat :

Tabel 3 Prediksi Umur TPA Sorat

\begin{tabular}{ccccccc}
\hline $\begin{array}{c}\text { Tahun } \\
\text { Ke }\end{array}$ & Tahun & $\begin{array}{c}\text { Akumulasi } \\
\text { Timbunan } \\
\left(\mathbf{m}^{\mathbf{3}} \text { /tahun) }\right.\end{array}$ & $\begin{array}{c}\text { Tinggi } \\
\text { timbunan } \\
(\mathbf{m})\end{array}$ & $\begin{array}{c}\text { Kebutuhan } \\
\text { Lahan } \\
\text { zonaTimbunan } \\
\left(\mathbf{m}^{\mathbf{2}}\right)\end{array}$ & $\begin{array}{c}\text { Kebutuhan } \\
\text { Lahan } \\
\text { zonaTimbunan } \\
\mathbf{( H a )}\end{array}$ & $\begin{array}{c}\text { Lahan Zona } \\
\text { Timbunan } \\
\text { yang } \\
\text { dipersiapkan } \\
\text { (Ha) }\end{array}$ \\
\hline 0 & 2016 & 8.865 & 10 & 886 & 0,09 & 1,25 \\
1 & 2017 & 18.412 & 10 & 1.841 & 0,18 & 1,25 \\
2 & 2018 & 28.665 & 10 & 2.867 & 0,29 & 1,25 \\
3 & 2019 & 39.650 & 10 & 3.965 & 0,40 & 1,25 \\
4 & 2020 & 51.392 & 10 & 5.139 & 0,51 & 1,25 \\
5 & 2021 & 63.914 & 10 & 6.391 & 0,64 & 1,25 \\
6 & 2022 & 77.243 & 10 & 7.724 & 0,77 & 1,25 \\
7 & 2023 & 91.403 & 10 & 9.140 & 0,91 & 1,25 \\
8 & 2024 & 106.419 & 10 & 10.642 & 1,06 & 1,25 \\
9 & 2025 & 122.315 & 10 & 12.231 & 1,22 & 1,25 \\
10 & 2026 & 139.117 & 10 & 13.912 & 1,39 & 1,25 \\
\hline
\end{tabular}

Sumber : Hasil Analisis, 2016

Menurut penyajian tabel diatas didapatkan bahwa umur lahan TPA adalah 9 tahun, karena pada tahun ke 9 TPA akan mulai mengalami kelebihan kapasitas muatan pada zona timbunan sampah sedangkan lahan yang disediakan untuk zona timbunan 
sampah adalah sebesar 1,25 Ha dengan tingkat pelayanan sebesar 47-65\%. Sehingga pada tahun 2025 harus diadakan pengembangan zona timbunan sampah yang baru.

\section{G Evaluasi Teknik Operasional}

Pada Tabel berikut akan dilaporkan mengenai evaluasi teknik operasional persampahan di Kecamatan Sambas dengan cara membandingkan konsisi eksisting di lapangan dengan ketentuan operasional yang diatur didalam SNI 19-2454-2002.

Tabel 4 Evaluasi Teknik Operasioal Persampahan Dengan Membandingkan Kondisi Eksisting Dan Kriteria SNI 19-2454-2002

\begin{tabular}{|c|c|c|c|}
\hline Teknik Operasional & Kriteria SNI & Kondisi Eksisting & Hasil Observasi \\
\hline \multirow[t]{5}{*}{ Pewadahan Sampah } & $\begin{array}{l}\text { Pemilahan sampah organik } \\
\text { dan anorganik }\end{array}$ & $\begin{array}{l}\text { Sampah masih tercampur } \\
\text { antara sampah organik \& } \\
\text { anorganik pada satu } \\
\text { wadah. }\end{array}$ & Tidak sesuai SNI \\
\hline & $\begin{array}{l}\text { Kriteria lokasi dan } \\
\text { penempatan wadah sampah }\end{array}$ & $\begin{array}{l}\text { Wadah individual } \\
\text { ditempatkan pada } \\
\text { halaman muka. Wadah } \\
\text { komunal diletakkan } \\
\text { sedekat mungkin dengan } \\
\text { sumber sampah. }\end{array}$ & Sesuai SNI \\
\hline & $\begin{array}{l}\text { Persyaratan bahan wadah } \\
\text { sampah }\end{array}$ & $\begin{array}{l}\text { Tidak mudah rusak dan } \\
\text { kedap air, ekonomis, } \\
\text { mudah dikosongkan. }\end{array}$ & Sesuai SNI \\
\hline & $\begin{array}{l}\text { Penentuan ukuran wadah } \\
\text { sampah }\end{array}$ & $\begin{array}{l}\text { Volume wadah sudah } \\
\text { menyesuaikan pada } \\
\text { kebutuhan pada setiap } \\
\text { rumah dari segi timbulan } \\
\text { sampah. }\end{array}$ & Sesuai SNI \\
\hline & Pengadaan wadah sampah & $\begin{array}{l}\text { Pengadaan wadah untuk } \\
\text { individual dilakukan oleh } \\
\text { pribadi atau instansi atau } \\
\text { pengelola, wadah sampah } \\
\text { komunal oleh instansi } \\
\text { pengelola. }\end{array}$ & Sesuai SNI \\
\hline \multirow[t]{3}{*}{ Pengumpulan Sampah } & $\begin{array}{l}\text { Peran serta masyarakat } \\
\text { tinggi }\end{array}$ & $\begin{array}{l}\text { Masyarakat aktif dalam } \\
\text { melakukan pembuangan } \\
\text { sampah pada TPS yang } \\
\text { sudah disediakan dan } \\
\text { pada jam yang sudah } \\
\text { ditetapkan oleh pengelola } \\
\text { persampahan. }\end{array}$ & Sesuai SNI \\
\hline & $\begin{array}{l}\text { Wadah komunal } \\
\text { ditempatkan sesuai dengan } \\
\text { kebutuhan dan lokasi yang } \\
\text { mudah dijangkau }\end{array}$ & $\begin{array}{l}\text { Wadah komunal /TPS } \\
\text { ditempatkan pada depan } \\
\text { komplek perumahan dan } \\
\text { dipinggir pasar. }\end{array}$ & Sesuai SNI \\
\hline & $\begin{array}{l}\text { Lahan untuk lokasi } \\
\text { pemindahan tersedia }\end{array}$ & $\begin{array}{l}\text { Wadah komunal /TPS } \\
\text { diletakan pada depan } \\
\text { komplek namun masih } \\
\text { dekat dengan jalan raya }\end{array}$ & Tidak Sesuai SNI \\
\hline
\end{tabular}




\begin{tabular}{|c|c|c|}
\hline & $\begin{array}{l}\text { sehingga menggangu } \\
\text { pengguna jalan raya saat } \\
\text { proses pemindahan } \\
\text { kontainer. }\end{array}$ & \\
\hline $\begin{array}{l}\text { Lebar jalan dapat dilalui alat } \\
\text { pengumpul tanpa } \\
\text { menggangu pemakai jalan } \\
\text { lainnya }\end{array}$ & $\begin{array}{l}\text { Lebar jalan di kecamatan } \\
\text { sambas memiliki ukuran } \\
\text { yang tidak lebar sehingga } \\
\text { posisi truck saat } \\
\text { melakukan pemindahan } \\
\text { sampah menggungu } \\
\text { pengguna jalan. }\end{array}$ & Tidak Sesuai SNI \\
\hline $\begin{array}{l}\text { Organisasi pengelola } \\
\text { sampah }\end{array}$ & $\begin{array}{l}\text { Organisasi pengelola } \\
\text { sampah diambil alih oleh } \\
\text { Dinas PU bidang } \\
\text { Kebersihan, Pertamanan } \\
\text { \& Perkuburan Kab. } \\
\text { Sambas. }\end{array}$ & Sesuai SNI \\
\hline $\begin{array}{l}\text { Harus mudah keluar masuk } \\
\text { bagi sarana pengumpul dan } \\
\text { pengangkut sampah }\end{array}$ & $\begin{array}{l}\text { Kondisi jalan yang sempit } \\
\text { tidak terlalu mengganggu } \\
\text { karena ada petugas yang } \\
\text { bertanggung jawab } \\
\text { mengatur lalu lintas. }\end{array}$ & Sesuai SNI \\
\hline $\begin{array}{l}\text { Tidak jauh dari sumber } \\
\text { sampah }\end{array}$ & $\begin{array}{l}\text { TPS berada didekat } \\
\text { komplek perumahan dan } \\
\text { pasar serta areal } \\
\text { perkantoran. }\end{array}$ & Sesuai SNI \\
\hline $\begin{array}{l}\text { Tempat penampungan } \\
\text { sementara berupa } \\
\text { kontainer }\end{array}$ & $\begin{array}{l}\text { Kondisi TPS masih } \\
\text { bersifat konvensional } \\
\text { sehingga pemindahan } \\
\text { sampah dilakukan secara } \\
\text { manual. }\end{array}$ & Tidak Sesuai SNI \\
\hline $\begin{array}{l}\text { Pola pengangkutan sampah } \\
\text { dengan sistem } \\
\text { pengosongan container }\end{array}$ & $\begin{array}{l}\text { Pengangkutan sampah } \\
\text { masih dilakukan dengan } \\
\text { pola pengangkutan } \\
\text { sampah individual } \\
\text { langsung. }\end{array}$ & Tidak Sesuai SNI \\
\hline $\begin{array}{l}\text { Alat pengangkut sampah } \\
\text { menggunakan armroll truck }\end{array}$ & $\begin{array}{l}\text { Alat pengangkut sampah } \\
\text { masih berupa dump } \\
\text { truck. }\end{array}$ & Tidak Sesuai SNI \\
\hline
\end{tabular}

Sumber : Hasil Analisis, 2016

Setelah menganalisis tabel diatas dapat diberikan beberapa rekomendasi untuk menjadi bahan masukan kepada pihak penanggung jawab teknik operasional di Kecamatan Sambas yakni Bidang Kebersihan, Pertaman, dan Perkuburan Dinas Pekerjaan Umum Kecamatan Sambas. Berikut rekomendasi yang dapat diberikan yaitu :

1. Pemerintah daerah perlu menambah sarana untuk menunjang pelaksanaan operasional persampahan yang berada di Kecamatan Sambas seperti pengadaan kendaraan pengangkut sampah dan pengadaan kontainer di setiap tempat pembuangan sementara. 
2. Pemerintah daerah harus menyiapkan sistem $3 R$ (Reduce, Recycle, Reuse). Dengan diterapkan sistem $3 R$, ditargetkan dapat mengurangi volume sampah yang masuk ke TPA. Sehingga sampah yang masuk ke TPA murni residu dari volume sampah yang tidak dapat dimanfaatkan kembali.

3. Pihak Penanggung jawab operasional persampahan di Kecamatan Sambas hendaknya mengkaji ulang setiap tahapan operasional persampahan untuk memperbaiki sistem operasional persampahan agar dapat menerapkan ketentuan yang berlaku pada SNI 19-2454-2002.

\section{KESIMPULAN}

1. Pada tahun 2025 dibutuhkan sarana operasional persampahan yaitu sejumlah 8 unit kontainer dan untuk sarana operasional pengangkutan sampah yang dibutuhkan sejumlah 3 unit armroll truck. Luas Lahan yang disiapkan untuk zona timbunan sebesar 1,25 $\mathrm{Ha}$, dan umur pada zona timbunan di TPA Sorat diprediksi dapat menampung timbunan sampah hingga 9 tahun kedepan dengan total akumulasi timbunan sebesar 122.315 $\mathrm{m}^{3}$, terhitung mulai tahun 2016 hingga tahun 2025 .

2. Teknik operasional persampahan di Kecamatan Sambas masih belum secara menyeluruh menerapkan sistem teknik operasional yang telah diatur dalam SNI 19-2454-2002. Hanya operasional pewadahan sampah dan pemindahan sampah yang sudah dinilai hampir seluruhnya memenuhi kriteria, sedangkan operasional pengumpulan dan pengangkutan sampah masih belum memenuhi kriteria pada SNI 19-2454-2002.

\section{UCAPAN TERIMA KASIH}

Dengan selesainya penelitian ini saya mengucapkan terima kasih yang sebesar-besarnya kepada Tuhan Yang Maha Esa, kedua orang tua, kedua dosen pembimbing yaitu Ibu Dian Rahayu Jati, S.T., M.Si. dan Ibu Yulisa Fitrianingsih, S.T., M.T. serta kepada teman-teman Teknik Lingkungan dan semua orang yang telah berperan dalam membantu penelitian yang tidak dapat disebutkan satu persatu. Harapan saya penelitian ini bermanfaat dan dapat dipergunakan sebagaimana mestinya.

\section{DAFTAR PUSTAKA}

Adioetomo, S. M. dan Samosir, O. B. 2010. Dasar - dasar Demografi edisi 2. Jakarta: Penerbit Salemba Empat.

BPS Kabupaten Sambas. 2014. Kabupaten Sambas Dalam Angka 2014. Badan Pusat Statistik. Kabupaten Sambas.

Damanhuri, Enri. 2010. Diktat Kuliah Pengelolaan Sampah. Institut Teknologi Bandung. Jawa Barat.

Dinas Pekerjaan Umum Kabupaten Sambas. 2012. Detail Engineering Design TPA Sorat Kabupaten Sambas. Kabupaten Sambas.

Dinas Pekerjaan Umum Kabupaten Sambas. 2015. Profil Kebersihan Kabupaten Sambas tahun 2015. Kabupaten Sambas.

SNI 19-3983-1995. Spesifikasi Timbulan Sampah Untuk Kota Kecil dan Kota Sedang di Indonesia.

SNI 19-2454-2002. Tata-Tata Cara Teknik Operasional Pengelolaan Sampah Perkotaan.

SNI 3242-2008. Pengelolaan Sampah Di Permukiman.

Tchobanoglus, G., Hillary, Theisen., and Samuel, Virgil., 1993, Integreted Solid Waste Management : Engineering Principles and Management Issues, McGraw Hill Publishing Company, New York. 